\title{
A Comparison of the Role of Dynorphin in the Hippocampal Mossy Fiber Pathway in Guinea Pig and Rat
}

\author{
Paul A. Salin, Marc G. Weisskopf, and Roger A. Nicoll \\ Department of Cellular and Molecular Pharmacology and Department of Physiology, University of California at San \\ Francisco, San Francisco, California 94143
}

\begin{abstract}
Several behavioral studies in rat (Gallagher, 1988) have suggested that opioids in the hippocampus could play an important role in learning and memory. However, in this species, very few reports specifically address the issue of physiological actions of opioids released by the mossy fibers which constitute the principal source of dynorphin and enkephalin in the hippocampus. In the guinea pig high frequency stimulation of mossy fibers causes a transient heterosynaptic inhibition of neighboring mossy fibers (Weisskopf et al., 1993) or perforant path synapses in the dentate (Wagner et al., 1993), which is mediated by the synaptic release of dynorphin that activates presynaptic к receptors. We show here that neither exogenous nor endogenous dynorphin affect mossy fiber excitatory postsynaptic potentials in the Sprague-Dawley rat, which is consistent with the finding that $\kappa$ receptor binding in the mossy fiber termination zone is dense in the guinea pig and sparse in this rat. More surprisingly, although $\kappa$ receptor binding is found in the rat dentate gyrus molecular layer and in the CA3 pyramidal cell layer, dynorphin had no action on perforant path field responses, somatic potassium currents or evoked monosynaptic inhibitory postsynaptic currents in CA3 cells. This lack of action appears to be an exception among rodents as dynorphin significantly inhibited mossy fiber responses in the hamster, mouse, and even another strain of rat, Long-Evans. Unlike the $\kappa$ mediated actions, the $\mu$ opioid receptor agonist DAMGO inhibited Sprague-Dawley mossy fiber responses, as it does in guinea pig. In contrast to other investigators, however, we found that the opioid receptor antagonist naloxone had no effect on Sprague-Dawley mossy fiber LTP.
\end{abstract}

[Key words: hippocampus, mossy fibers, long term potentiation, opioids, dynorphin, $\kappa$ receptor]

Immunohistochemical studies have shown that opioid peptides, and in particular dynorphin, are present in high amounts in hippocampal mossy fibers of many species including guinea pig, rat, squirrel, hamster, mouse, monkey, and human (Khachaturian et al., 1982; McGinty et al., 1983; Lewis et al., 1984; Fallon and Leslie, 1986; McLean et al., 1987; Gall, 1988; Houser et al.,

\footnotetext{
Received Feb. 22, 1995; revised May 22, 1995; accepted May 24, 1995.

This research was supported by the NIMH. R.A.N. is a member of the Keck Center for Integrative Neuroscience and the Silvio Conte Center for Neuroscience Research. We thank Dr. T. Reisine for discussion.

Correspondence should be addressed to Roger A. Nicoll, Department of Pharmacology, University of California at San Francisco, San Francisco, CA 94143.

Copyright $(\mathcal{C} 1995$ Society for Neuroscience $0270-6474 / 95 / 156939-07 \$ 05.00 / 0$
}

1990). Despite the uniformity in the hippocampal distribution of dynorphin among different species, the distribution of $\kappa$ receptors, the preferred opioid receptor for dynorphin, differs among species (Lewis et al., 1984; Foote and Maurer, 1986; Sharif and Hughes, 1989; Kornblum et al., 1987; Mansour et al., 1987; McLean et al., 1987; Tempel and Zukin, 1987). In particular, in most species $\kappa$ receptor binding is high in $\mathrm{s}$. lucidum, the termination zone of the mossy fibers. However, in the rat the receptor binding is not in s. lucidum but is found in the pyramidal cell layer. In guinea pigs, we have recently studied the physiological role of dynorphin in the mossy fiber pathway (Weisskopf et al., 1993). Application of dynorphin caused a presynaptic inhibition of glutamate release from mossy fibers by activating $\mathrm{k}$ opioid receptors. In addition tetanization of mossy fibers resulted in an opioid-mediated heterosynaptic inhibition of mossy fiber responses and a homosynaptic inhibition of the induction of mossy fiber long-term potentiation (LTP). This last finding is in striking contrast to reports that in the rat blockade of opioid receptors by naloxone blocks mossy fiber LTP (Derrick et al., 1991; Williams and Johnston, 1992). A separate debate exists in the literature as to whether guinea pigs belong in the rodent order (Graur et al., 1991; Hasegawa et al., 1992; Martigaretti and Brosius, 1993). Because of these controversies and the well documented species differences in the distribution of opioid receptor binding we have carried out a detailed study on the possible role of opioids in the rat hippocampal mossy fiber system.

\section{Materials and Methods}

Slice preparation. Experiments were performed using hippocampal slices from male Hartley guinea pigs (Simonsen, 2-5 weeks), male Sprague-Dawley rats (Simonsen, 4-10 wecks), male Long-Evans rats (Simonsen, 6-10 weeks), male C57BL/6N mice (Simonsen, 4-10 weeks), male DBA/2 mice (Simonsen, 10 weeks), and male Syrian hamsters (Simonsen, 4-10 weeks). Animals were anesthetized with halothane and decapitated, and the hippocampi were removed, placed in ice cold Ringer's and cut with a vibratome in $500 \mu \mathrm{m}$ thick slices. After at least $1 \mathrm{hr}$ for recovery, slices were transferred to a submersion chamber for recording. The Ringer's contained $119 \mathrm{mM} \mathrm{NaCl}, 2.5 \mathrm{mM} \mathrm{KCl}$, $1.3 \mathrm{mM} \mathrm{MgSO}_{4}, 2.5 \mathrm{mM} \mathrm{CaCl}_{2}, 26 \mathrm{mM} \mathrm{NaHCO}_{3}, 1 \mathrm{mM} \mathrm{NaH}_{2} \mathrm{PO}_{4}$, and $10 \mathrm{mM}$ glucose and was equilibrated with $95 \% \mathrm{O}_{2}$ and $5 \% \mathrm{CO}_{2}$. Experiments were done at room temperature.

Recordings. Field recordings were made with electrodes filled with $3 \mathrm{M} \mathrm{NaCl}$. When recording mossy fiber inputs, the contribution of axons other than mossy fiber to the evoked synaptic response was reduced by the following procedures: (1) the stimulating electrode was placed in stratum lucidum while the field electrode was moved to different recording sites in stratum granulosum in order to get the largest antidromic field potential and subsequently the stimulating electrode was placed at this location; (2) when the stimulating electrode was placed in stratum granulosum, the mossy fiber field response recorded in the CA 3 region had to show a sink in stratum lucidum and a source in stratum radiatum. At the end of the recording session the AMPA receptor antagonist 
Figure 1. In rat, high frequency stimulation of one of two independent mossy fiber pathways does not induce inhibition of the untetanized pathway. Rat slices (left-hand panel, $n=6$ ) were interleaved with guinea pig slices (right-hand panel, $n=5$ ). A1, After baseline responses were stable for at least $10 \mathrm{~min}$, a tetanus was given at time 0 . Rat mossy fiber responses of the tetanized pathway show LTP. A2, Concurrently recorded, responses of the untetanized pathway exhibit a slight transient potentiation instead of a depression. $B I$, The tetanized guinea pig mossy fiber pathway exhibits LTP while the untetanized input $(B 2)$ shows a transient depression.
A1

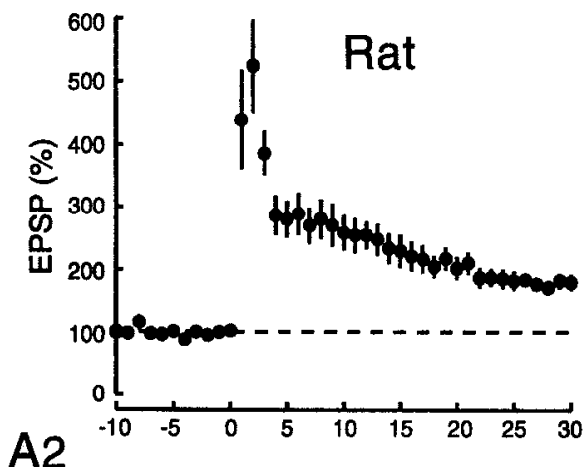

A2

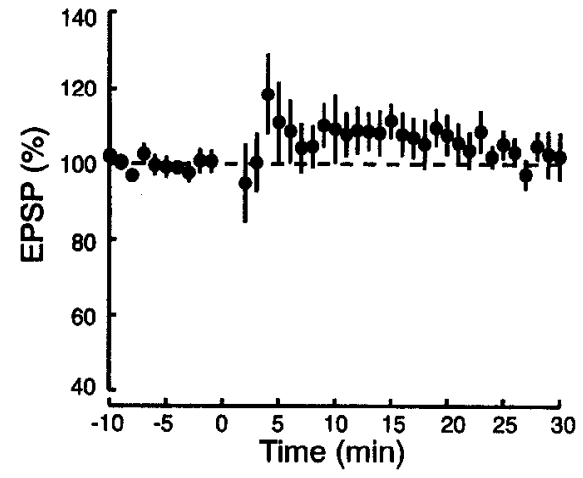

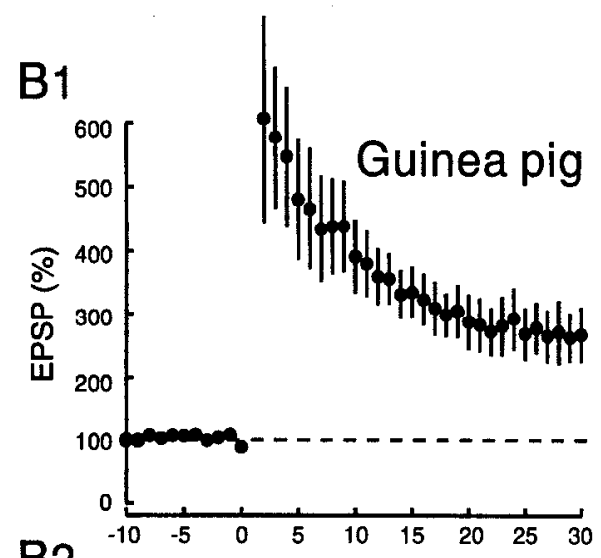

B2

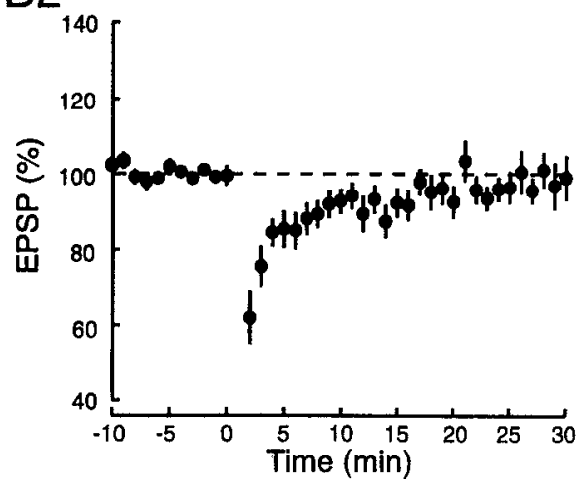

CNQX $(20 \mu \mathrm{M})$ was added to the perfusion solution in order to determine the contribution of fiber volley to the field response. The fiber volley response was subtracted from all records during analysis. The tetanus used to induce LTP consisted of four trains of $100 \mathrm{~Hz}$ for $1 \mathrm{sec}$ separated by $20 \mathrm{sec}$. During the tetanus, the perfusion medium included 25-50 $\mu \mathrm{M}$ D-APV which does not block mossy fiber LTP (Harris and Cotman, 1986; Zalutsky and Nicoll, 1990), but prevents contamination by NMDA-dependent LTP. When recording perforant path synaptic responses picrotoxin $(100 \mu \mathrm{M})$ was applied to the perfusion solution and the concentrations of $\mathrm{MgSO}_{4}$ and $\mathrm{CaCl}_{2}$ were increased to $4 \mathrm{~mm}$. Stimulation and recording electrodes were both placed in the outermost twothirds of the molecular layer, approximately $400 \mu \mathrm{m}$ apart. In rats and mice small concentric bipolar stimulating electrodes were used to restrict the range of stimulated axons.

Intracellular recordings from $\mathrm{CA} 3$ pyramidal cells were made using the whole-cell patch-clamp technique (Blanton et al., 1989) or standard sharp electrodes $(60-90 \mathrm{M} \Omega 3 \mathrm{M} \mathrm{KCl})$. Whole-cell currents were amplified using an Axopatch-1D. Discontinuous single electrode voltage clamp recordings were made with an Axoclamp 2A. The headstage was continously monitored. The internal solutions for the whole-cell pipettes consisted of $135 \mathrm{~mm}$ cesium gluconate, $10 \mathrm{mM}$ HEPES, $0.2 \mathrm{~mm}$ EGTA, $2 \mathrm{~mm} \mathrm{Mg-ATP}, 0.3 \mathrm{~mm} \mathrm{Na}$-GTP, and $4 \mathrm{~mm} \mathrm{NaCl}$ when recording evoked monosynaptic inhibitory postsynaptic currents (IPSCs). To record monosynaptic IPSCs (Davies et al., 1990), CNQX (10 $\mu \mathrm{M})$ and D-APV $(25 \mu \mathrm{M})$ were added to the bath solution. When recording voltage gated potassium currents, $130 \mathrm{~mm}$ potassium gluconate was used instead of cesium gluconate. Recordings of outward potassium currents either with whole-cell or sharp electrode recording were usually performed in the presence of picrotoxin $(100 \mu \mathrm{M})$, CNQX $(10 \mu \mathrm{M})$, and tetrodotoxin $(0.3-1 \mu \mathrm{M})$. Cells were held at -40 to $-55 \mathrm{mV}$ and 5-15 $\mathrm{mV}$ hyperpolarizing steps (1-2 sec duration) were applied to switch off the M-current. The inward relaxation during the step was shown to result from closure of $\mathrm{M}$ channels by its blockade by carbachol $(30 \mu \mathrm{M})$ at the end of the experiment. When specifically testing for effects on M-current, Cs (2mM) was added to the medium to block $\mathrm{I}_{\mathrm{O}}$ (IIalliwell and Adams, 1982). The patch pipettes had resistances of 4-6 M 2 Drugs were purchased from Cambridge Research Biochemicals (CNQX, APV), Bachem [dynorphin A (1-17)], Endo Labs (naloxone HCL) and Sigma (carbachol, DAMGO, U69593).

\section{Results}

We first looked for the presence of an opioid-mediated heterosynaptic inhibition of mossy fiber synapses in the rat, similar to that previously reported in the guinea pig (Weisskopf et al., 1993). In the rat, however, we were unable to see any evidence for the existence of such a phenomenon (Fig. 1A). Instead, a small amount of potentiation was seen in these experiments, which is similar to the results in guinea pig in the presence of naloxone (Weisskopf et al., 1993). This potentiation most likely resulted from a few fibers that were activated by both electrodes. The tetanization protocol used for these experiments in rats were also used for a set of interleaved experiments in guinea pigs, and as expected the typical heterosynaptic inhibition was seen (Fig. 1B).

One possible reason for the negative result in rat is that the mossy fibers of the rat, although they release dynorphin, may lack the proper receptors. Indeed, as shown in Figure $2 A 1$ rat mossy fiber synaptic responses were entirely unaffected by dynorphin. During these experiments we also carried out experiments on guinea pigs to ensure that the dynorphin was capable of causing its usual effect. We next examined the perforant path since dynorphin has been shown to inhibit transmission between perforant path fibers and granule cells in the guinea pig (Wagner et al., 1992; Wagner et al., 1993) and $\kappa$ receptor binding has been reported in the molecular layer of the dentate gyrus of the rat (Kornblum et al., 1987; McLean et al., 1987). However, while dynorphin had its usual depressant effect in the guinea pig, it failed to exert any effect in the rat (Fig. 2BI). In addition the $\kappa 1$ receptor agonist U69,593 (300 nM) had no action on mossy fiber $(n=5)$ or perforant path synaptic responses $(n=$ 4 ) in the rat. On the other hand, in interleaved slices from guinea pig, bath application of U69,593 depressed mossy fiber $(n=7)$ 

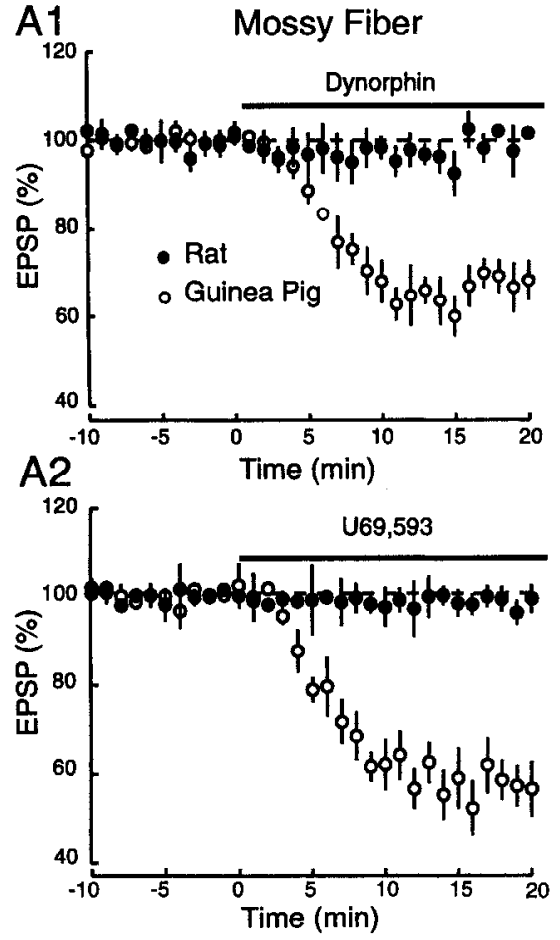
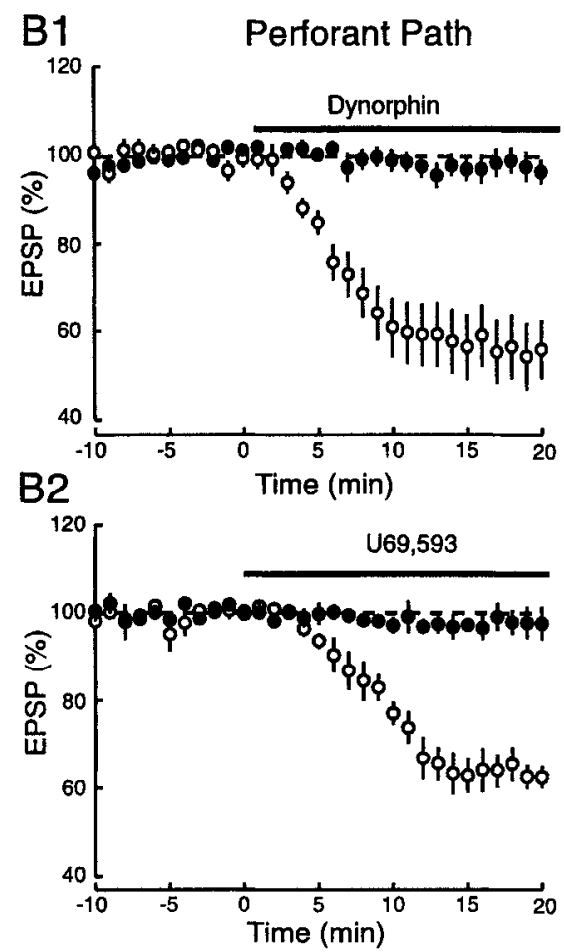

Figure 2. $\kappa_{1}$ Selective agonists have no action on mossy fiber and perforant path responses in the rat. Al, After baseline responses were stable for at least $10 \mathrm{~min}$, dynorphin (500 $\mathrm{nM}$ ) was added to the perfusion solution. An inhibition of mossy fiber responses was obtained in guinea pig (open circles, $n=5$ ), but not in rat (solid circles, $n=6$ ) slices. A2, Application of U69,593 (300 nM) inhibited mossy fiber responses in the guinea pig (open circles, $n=7$ ), but not in the rat (solid circles, $n=5$ ). $B 1$, Similar results after application of dynorphin were obtained on perforant path field potential responses in guinea pig (open circles, $n=8$ ) and in rat (solid circles, $n=11$ ) slices. B2, Application of $\mathrm{U} 69,593$ also inhibited perforant path responses in the guinea pig (open circles, $n=5$ ), but not in the rat (solid circles, $n=4$ ). and perforant path fields ( $n=5$ ) as reported previously by Weisskopf et al. (1993) and Wagner et al. (1993), respectively (Fig. $2 A 2, B 2)$. The U69,593 depression of mossy fiber responses in the guinea pig establishes the presence of functional $\kappa 1$ receptors in the CA3 region, contrary to previous binding (Wagner et al., 1991) and electrophysiological (Caudle and Chavkin, 1990) studies.

Since $\kappa$ receptor binding in the Sprague-Dawley rat CA3 region is concentrated over the pyramidal cell layer we considered two possible targets for these binding sites. First, we tested the possibility that these binding sites were on the pyramidal cell body and targeted voltage gated channels in the postsynaptic cell. In particular we examined whether dynorphin might open potassium channels as it (Grudt and Williams, 1993) and other opioids (North et al., 1987; Madison and Nicoll, 1988; Wimpey and Chavkin, 1991) do in other neurons. Dynorphin (500 nM to $1 \mu \mathrm{M})$ failed to activate an outward current in rat CA3 pyramidal cells $(n=7)$, while the $\mathrm{GABA}_{\mathrm{B}}$ receptor agonist baclofen, which opens the same class of potassium channels as opioids in other neurons (Andrade et al., 1986; North et al., 1987), did cause a large outward current associated with an increase in conductance (Fig. 3A) $(n=7)$. The $\mathrm{k}$ receptor agonist U69,593 (300 nM) also had no effect $(n=4)$. In guinea pig CA3 pyramidal cells dynorphin $(1 \mu \mathrm{M})$ also failed to alter the holding current $(n=$ 4). It has recently been reported that $100 \mathrm{~nm}$ dynorphin enhances the M-current (Moore, 1994). However, we found that, while activation of muscarinic receptors with carbachol inhibited the inward relaxation recorded during the hyperpolarizing voltage step, dynorphin (100 nM, $n=11 ; 1 \mu \mathrm{M}, n=5$ ) did not affect this current or the holding current (Fig. $3 B$ ).

We considered the possibility that the binding sites for dynorphin in the pyramidal cell layer were on the terminals of inhibitory neurons, since these are concentrated on the soma and initial segment and it is well established that inhibitory neurons express other opioid receptors (Cohen et al., 1992; Capogna et al., 1993). However, although monosynaptically evoked IPSCs were inhibited by the $\mu$ selective agonist DAMGO, dynorphin had no effect (Fig. $3 C)(n=6)$.

Given the striking differences between the effects of dynorphin in the rat and guinea pig, the question arises as to which one of these species is atypical. We therefore examined the effect of dynorphin on mossy fiber responses in two species closely related to the rat. In both the hamster (Fig. 4A) and the mouse (Fig. $4 B$ ), dynorphin was found to inhibit synaptic transmission, although the effect was somewhat less than in guinea pig. These results would suggest that the rat is the atypical species. However, we considered whether a difference might exist between strains of rat and therefore compared the effects of dynorphin on mossy fiber synaptic responses of Sprague-Dawley and Long-Evans (hooded) rats. Surprisingly, mossy fiber responses in Long-Evans rats were inhibited by dynorphin (Fig. 5A). Superimposed on this graph is the averaged results from interleaved Sprague-Dawley rats, confirming the results in Figure $2 A$ indicating a lack of effect of dynorphin in this strain. Since different strains of mice show different susceptibility to naloxone on cognitive tasks (Gallagher, 1988), we have examined for differences between the $\mathrm{DBA} / 2$ and $\mathrm{C} 57 \mathrm{BL} / 6$ strains of mice. However, dynorphin inhibited mossy fiber responses in both strains to a similar degree (Fig. $5 B$ ).

Since activation of $\mu$ opioid receptors can also depress mossy fiber synaptic transmission in the guinea pig (Weisskopf et al., 1993), and since mossy fibers in the rat contain the $\mu$ ligand enkephalin (McLean et al., 1987), we examined whether mossy fibers of the Sprague-Dawley rat might be sensitive to $\mu$ opioid agonists. A modest inhibition was observed with the $\mu$ selective agonist, DAMGO, in both rat and guinea pig (Fig. 6) confirming that activation of $\mu$ receptors causes a small, but reproducible, inhibition of mossy fibers in both species.

$\Lambda$ s discussed in the introduction, the role of opioid receptors in mossy fiber LTP is controversial. The marked species differ- 


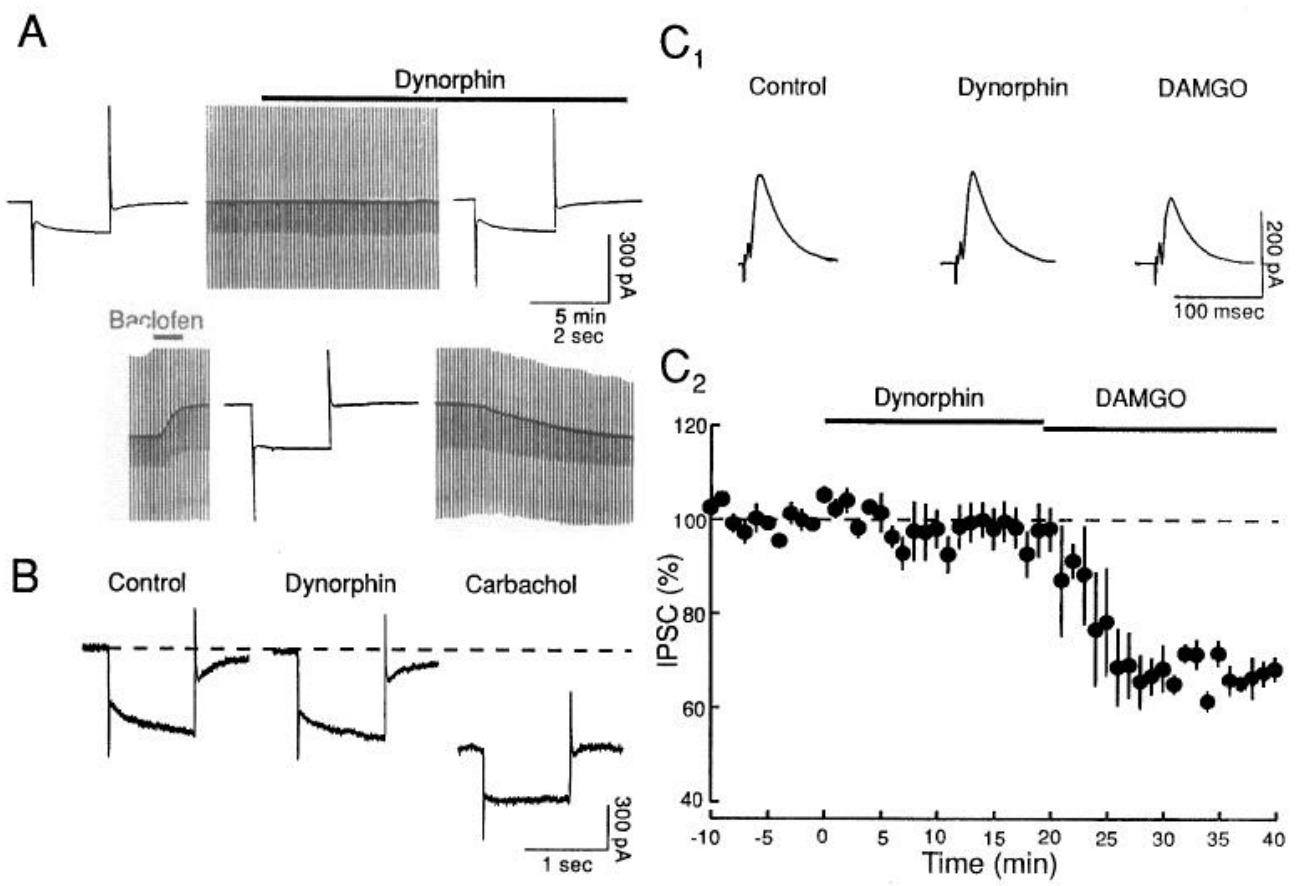

Figure 3. Dynorphin fails to activate potassium currents or block monosynaptic inhibitory postsynaptic currents in rat CA3 pyramidal cells. A, Chart record of a whole cell voltage-clamped neuron held at $-50 \mathrm{mV}$ with superimposed inward currents evoked by a $10 \mathrm{mV}$ hyperpolarizing voltage pulse ( $2 \mathrm{sec}$ duration, $0.66 \mathrm{~Hz}$ ). Bath application of dynorphin $(1 \mu \mathrm{M})$ had no effect on the steady state membrane current. The slow outward current induced by the $\mathrm{GABA}_{\mathrm{B}}$ agonist baclofen $(10 \mu \mathrm{M})$ demonstrated that the absence of effect of dynorphin is not due to a wash out of the neuron by the whole cell technique. Recordings were done in the presence of the AMPA receptor antagonist CNQX (10 $\mu \mathrm{M})$, the GABA receptor $_{\mathrm{A}}$ antagonist picrotoxin $(100 \mu \mathrm{M})$ and the $\mathrm{Na}$ channel blocker tetrodotoxin $(1 \mu \mathrm{M}) . B$, M-current relaxations recorded with a sharp electrode. The cell was held at $-40 \mathrm{mV}$ and a $10 \mathrm{mV}$ hyperpolarizing step was applied. Dynorphin (100 nM) was applied for 10 min and had no effect, either on the holding current or on the M-current relaxation. Carbachol $(30 \mu \mathrm{M})$ caused an inward shift in the holding current and blocked the M-current. The broken line represents the holding current during the control period. Each record is the average of 10 traces. $C l$, Single experiment showing that the $\mu$ receptor agonist DAMGO (100 nM), but not dynorphin $(500 \mathrm{nM})$, decreases the inhibitory postsynaptic currents (IPSC) in CA3 pyramidal cells. Each trace is the average of $10 \mathrm{IPSCs}$ recorded from a cell voltage clamped at $0 \mathrm{mV}$. C2, Summary of results for six cells. Recordings were done in the presence of CNQX $(10 \mu \mathrm{M})$ and the NMDA receptor antagonist D-APV $(25 \mu \mathrm{M})$.

ences in the opioid pharmacology seen in the present study raises the possibility that the reported blockade of mossy fiber LTP by naloxone in the rat might be due to a species difference. We therefore examined the effects of naloxone on mossy fiber LTP in the Sprague-Dawley rat. Control slices and slices exposed to naloxone $(10 \mu \mathrm{M})$ were interleaved. As shown in Figure 7, naloxone, applied for at least $20 \mathrm{~min}$, had no effect on LTP. This was not due to the ineffectiveness of our supply of naloxone in blocking opioid receptors, because during this series of negative experiments naloxone was fully effective in completely blocking the actions of dynorphin on guinea pig mossy fibers.

\section{Discussion}

In a previous study from this lab we found that tetanic stimulation of mossy fibers in the guinea pig releases dynorphin, which acts on presynaptic $\kappa$ receptors, resulting in a heterosynaptic inhibition of mossy fiber transmission (Weisskopf et al., 1993). A similar inhibition has been reported at perforant path to dentate granule cell synapses in the guinea pig (Wagner et al., 1993). The rationale for carrying out the present experiments was twofold. First, clear differences in the distribution of $\kappa$ receptor binding are known to exist in the rat compared to other species. Receptor autoradiography has revealed a high density
Figure 4. Dynorphin inhibits hamster and mouse mossy fiber responses. Extracellular field recordings are plotted against time. $A$, Time course of the effect of dynorphin $(500 \mathrm{nM})$ on hamster $(n=7)$ mossy fiber responses. $B$, Time course of the effect of dynorphin (500 $\mathrm{nM})$ on mouse $(n=6)$ mossy fiber responses. A modest reduction of field EPSP was observed.
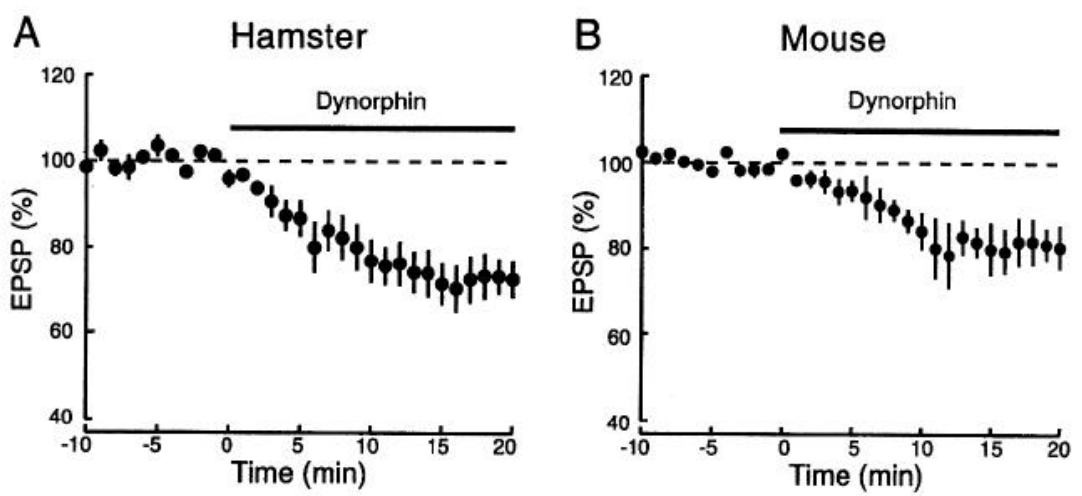

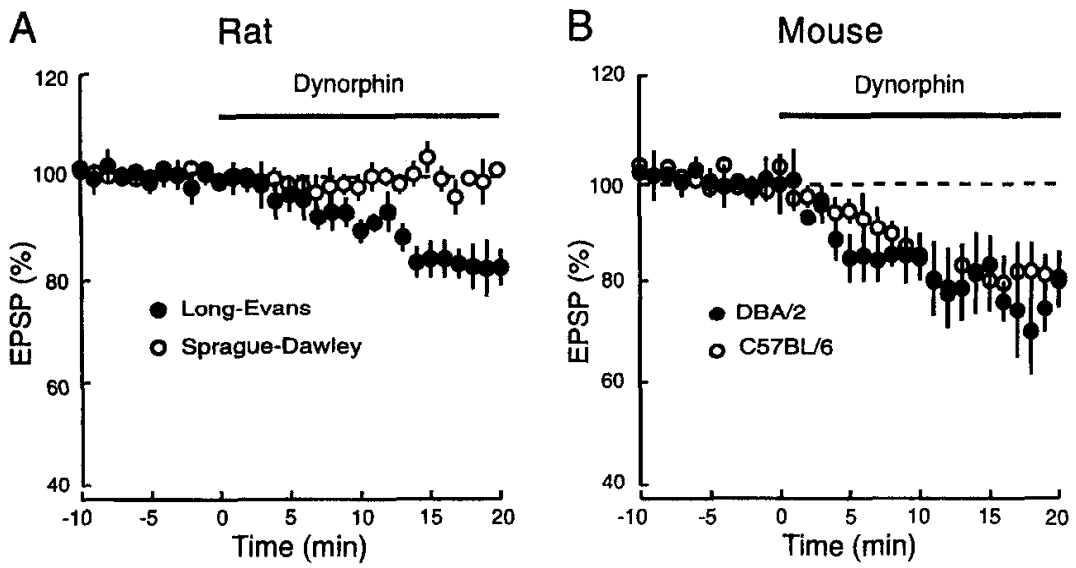

Figure 5. A comparison of dynorphin
responses in different strains of mouse
and rat. A, Dynorphin ( 500 nM) de-
creases mossy fiber responses in Long-
Evans rats (solid circles, $n=7$ ). Inter-
leaved slices from Sprague-Dawley
rats (open circles, $n=5$ ) confirm pre-
vious results that dynorphin has no ef-
fect in this strain of rat. $B$, Dynorphin
(500 nM) action on mouse mossy fiber
responses of the strain DBA $/ 2$ (solid
circles, $n=3$ ) and C57BL/6 (open cir-
cles; same data as shown in Fig. $4 B$ ).
The inhibitory effect of dynorphin was
the same for the two strains of mice.

peak of $k$ receptors in stratum lucidum and dentate molecular layer in squirrel, guinea pig, and hamster (Foote and Maurer, 1986; McLean et al., 1987). While previous binding studies in the guinea pig have suggested that only the $\kappa 2$ receptor subtype is present in stratum lucidum and that $\kappa 1$ is present in the molecular layer (Wagner et al., 1991), our dạta (Fig. 2 and Weisskopf et al., 1993) clearly establish functional $\kappa 1$ receptors in both regions. In contrast, the rat exhibits a high density zone of $\kappa$ receptors in the CA3 pyramidal layer and in the dentate granular layer (Kornblum et al., 1987; McLean et al., 1987; Tempel and Zukin, 1987). Moreover, even in these latter hippocampal regions, a quantitative analysis indicates that the density of $\kappa$ sites is lower in the rat than in the guinea pig (Sharif and Hughes, 1989). Recently it has been shown that granule cells in the dorsal dentate gyrus in the guinea pig express $\kappa 1$ receptor mRNA (Xie et al., 1994), while those in the rat do not (Mansour et al., 1994). In striking contrast with such a variability of receptor binding and expression, immunohistochemistry has shown that, in all these species, the mossy fibers are consistently dynorphin-positive (Fallon and Leslie, 1986; Khachaturian et al., 1982; McGinty et al., 1983; McLean et al., 1987; Weber et al., 1982). Second, while we found that opioid antagonists facilitate the induction of mossy fiber LTP in guinea pigs (Weisskopf et al., 1993), others, primarily using the rat, have reported that opioid antagonists block mossy fiber LTP (Derrick et al., 1991; Williams and Johnston, 1992). While we have found dramatic

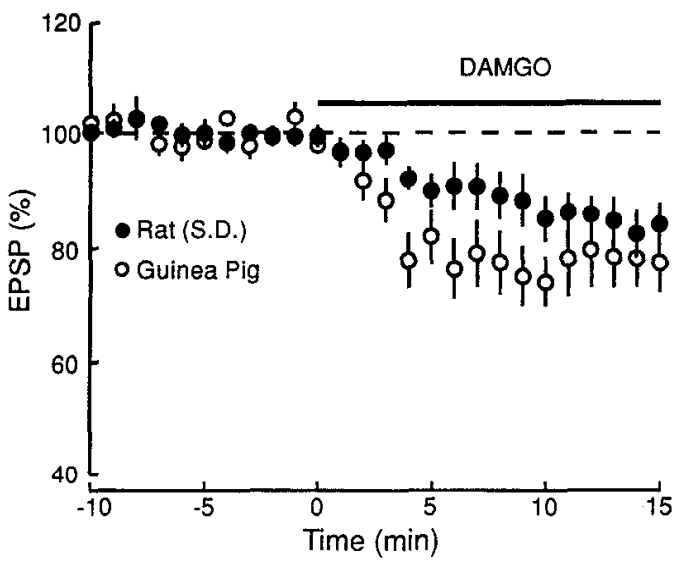

Figure 6. The $\mu$ receptor agonist DAMGO inhibits rat mossy fiber responses. Summary of the experiments of the time of DAMGO (100 nM) inhibition in Sprague-Dawley rat (solid circles, $n=9$ ) and in guinea pig (open circles, $n=6$ ) slices. differences in the opioid receptor pharmacology between these two species, we have been unable to resolve the controversy regarding the role of opioid receptors in mossy fiber LTP.

In a first series of experiments we were unable to find any action of dynorphin in the rat on either mossy fiber or perforant path synaptic transmission. Since $k$ receplor binding has been reported to be low in these areas, we looked for actions in the CA3 pyramidal cell layer where higher levels of binding have been reported. We were therefore interested in seeing if dynorphin activated the ubiquitous G-protein coupled inward rectifying $\mathrm{K}^{+}$current in CA3 pyramidal cells, as seen with opioid peptides in other neurons (Grudt and Williams, 1994; Madison and Nicoll, 1988; North, 1992; Wimpey and Chavkin, 1991). In none of the cells tested did we see an effect of dynorphin or U69,593 on the holding current or input resistance of rat CA3 pyramidal cells. Furthermore, in experiments specifically designed to maximize study of the M-current, we saw no effect of dynorphin (0.1-1 $\mu \mathrm{M})$ on $\mathrm{M}$-current relaxations or holding current, contrary to a previous report (Moore et al., 1994). To test whether the $\kappa$ receptor binding was associated with inhibitory synaptic terminals in the pyramidal cell layer, we tested for an effect of dynorphin on inonosynaptically evoked IPSCs. While the $\mu$ receptor agonist DAMGO inhibited IPSCs, in agreement with previous finding in the hippocampus (Cohen et al., 1992; Capogna et

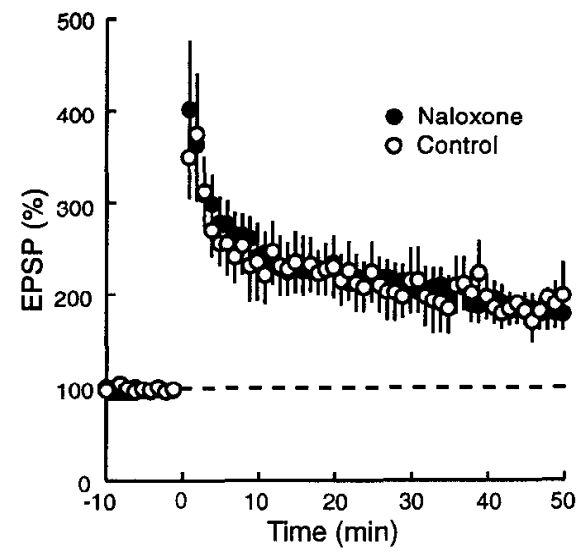

Figure 7. The opioid receptor antagonist naloxone has no effect on the induction of rat mossy fiber LTP. Normalized mossy fiber field potentials are plotted against time. The tetanus was given at time 0 . Control slices (open circles, $n=4$ ) were interleaved with slices bathed in the presence of naloxone $(10 \mu \mathrm{M}$, solid circles, $n=6)$. Naloxone was applied at least 20 min before the tetanus. The same amount of potentiation was obtained in control and in naloxone treated slices. 
al., 1993), dynorphin was without effect. Therefore, although anatomical evidence indicates a high density of binding for $\kappa$ receptor agonists in the pyramidal cell layer in the rat, we were unable to detect any physiological function for these binding sites. The present negative results, however, are consistent with the recent report that the dorsal rat hippocampus is devoid of $k$ 1 receptor mRNA (Mansour et al., 1994). The role of dynorphin in the rat mossy fiber system therefore remains unknown, and this report must be added to numerous reports in the literature in which extensive physiological investigation has failed to uncover any function for a peptide that has been localized to a specific set of neurons (Bowers, 1994).

Mossy fibers of various species contain enkephalins, in addition to dynorphin (Zamir et al., 1985; Fallon and Leslie, 1986; McLean et al., 1987; Gall, 1988). Enkephalins act primarily on $\mu$ opioid receptors and we previously found that $\mu$ selective agonists also had a modest depressant effect on mossy fiber responses in the guinea pig (Weisskopf et al., 1993). In the present study we found a similar effect of the $\mu$ selective agonist DAMGO on mossy fiber responses of the rat. Ilowever, in comparison to the guinea pig, the presence of enkephalin and $\mu$ opioid receptors in the rat clearly fail to substitute for the absence of the $\kappa$ opioid receptors, because mossy fibers in the rat did not exhibit a heterosynaptic inhibition. Therefore, either insufficient enkephalin is released from the mossy fibers upon tetanization or the effect of enkephalin on the mossy fibers is too small to be detected.

The second issue addressed in this article concerns the controversy that exists regarding the effects of the opioid receptor antagonist naloxone on mossy fiber LTP. We have found that naloxone facilitates the induction of LTP in the guinea pig (Weisskopf et al., 1993). Others using Sprague-Dawley rats (Derrick et al., 1991; Williams and Johnston, 1992), except for Martin (1983) who used guinea pigs, have reported that naloxone blocks LTP. Given this controversy, we reexamined this issue and failed to find any effect of naloxonc on mossy fibcr LTP in the Sprague-Dawley rat. We can, therefore, rule out species difference as an explanation for the different results.

Perhaps the most intriguing finding of the present study concerns the comparison of the action of dynorphin on mossy fibers in different species. In this regard, the guinea pig does not stand out from other rodents. The Sprague-Dawley rat, however, differs not only from rodents of different families (hamster and guinea pig), but also from a rodent of the same subfamily (mouse; see Nowak, 1991). Differences between the SpragueDawley rat and the guinea pig have also been found in other parts of the brain, in particular in the deep layers of neocortex (Goodman and Snyder, 1982; McLean et al., 1987; Tempel and Zukin, 1987; Sharif and Hughes, 1989). Moreover, in the rhesus monkey, the dentate molecular layer and neocortical deep layers, are also dense in $\kappa$ receptors, unlike the results observed in the Sprague-Dawley rat (Lewis et al., 1984; Slater and Cross, 1986; these studies do not report on the distribution of $\kappa$ receptors in stratum lucidum). Thus, in terms of the distribution of $\kappa$ receptors the Sprague-Dawley rat appears to be distinct from other mammals. To our surprise we found that, in contrast to the Sprague-Dawley rat, the Long-Evans rat showed an inhibitory effect of dynorphin on mossy fibers. Unfortunately, no data is available on the distribution of $\kappa$ receptor binding in Long-Evans rats. Most behavioral studies, however, have been carried out using Iong-Evans or other strains of rats (see Davis et al., 1992; Jiang et al., 1989; McDaniel et al., 1990). It would be of interest to compare the effects of naloxone on cognitive tasks in Sprague-Dawley and Long-Evans rats. Based on our findings with the DBA/2 and C57BL/6 strains of mice, however, the different effect of naloxone on the behavior in these two strains of mice (Gallagher, 1988) cannot be explained by differences in the action of dynorphin on mossy fibers.

The complete absence of a detectable role of dynorphin in the Sprague-Dawley rat mossy fiber system compared to other species raises a number of questions. For instance, how does the rat compensate for this absence in the action of dynorphin? Alternatively, is the clearly established synaptic transmitter role of dynorphin in the other species superfluous to an animal's behavior? In this regard it has been very difficult to establish a physiological role for the LHRH slow synaptic potential in the frog sympathetic ganglion (Bowers, 1994), which is one of the most thoroughly characterized peptidergic synapses in vertebrates (Jan and Jan, 1982). Detailed behavioral testing with naloxone may provide answers to these questions and establish a behavioral role for opioid peptides in hippocampal function. Given the selective and specific absence of a role of dynorphin in the Sprague-Dawley rat mossy fiber system, it would be interesting to determine if there are naloxone sensitive memory tasks that are selectively absent in the Sprague-Dawley rat.

\section{References}

Andrade R, Malenka RC, Nicoll RA (1986) A G protein couples serotonin and $\mathrm{GABA}_{B}$ receptors to the same channels in hippocampus. Science 234:1261-1265.

Blanton MG, Lo Turco JJ, Kriegstein AR (1989) Whole cell recording from neurons in slices of reptilian and mammalian cerebral cortex. $J$ Neurosci Methods 30:203-210.

Bowers CW (1994) Superfluous neurotransmitters? Trends Neurosci 17:315-320.

Capogna M, Gahwiler BH, Thompson SM (1993) Mechanism of muopioid receptor-mediated presynaptic inhibition in the rat hippocampus in vitro. J Physiol (Lond) 470:539-558.

Cohen GA, Doze VA, Madison DV (1992) Opioid inhibition of GABA release from presynaptic terminals of rat hippocampal interneurons. Neuron 9:325-335.

Davies CH, Davies SN, Collingridge GL (1990) Paired-pulse depression of monosynaptic GABA-mediatcd inhibitory postsynaptic responses in rat hippocampus. J Physiol (Lond) 424:513-531.

Davis S, Butcher SP, Morris RG (1992) The NMDA receptor antagonist D-2-amino-5-phosphonopentanoate (D-AP5) impairs spatial learning and LTP in vivo at intracerebral concentrations comparable to those that block LTP in vitro. J Neurosci 12:21-34.

Derrick BE, Weinberger SB, Martinez JL (1991) Opioid receptors are involved in an NMDA receptor-independent mechanism of LTP induction at hippocampal mossy fiber-CA3 synapses. Brain Res Bull 27:219-223.

Fallon JH, Leslie FM (1986) Distribution of dynorphin and enkephalin peptides in the rat brain. J Comp Neurol 249:293-336.

Foote RW, Maurer R (1986) Distribution of opioid binding sites in the guinea pig hippocampus as compared to the rat: a quantitative analysis. Ncuroscience 19:847-856.

Gall C (1988) Seizures induce dramatic and distinctly different changes in enkephalin, dynorphin, and CCK immunoreactivities in mouse hippocampal mossy fibers. J Neurosci 8:1852-1862.

Gallagher M (1988) Behavioral significance of opioid peptides in relation to hippocampal function. In: Opioids in the hippocampus (McGinty JF, Friedman DP, eds), pp 118-132. NIDA Res Monograph.

Goodman RR, Snyder SH (1982) Autoradiographic localization of adenosine receptors in rat brain using $\left\lceil^{3} \mathrm{H}\right\rceil$ cyclohexyladenosine. $\mathrm{J}$ Neurosci 2:1230-1241.

Graur D, Hide WA, Li W-H (1991) Is the guinea-pig a rodent? Nature $351: 649-652$

Grudt TJ, Williams JT (1993) Kappa-opioid receptors also increase potassium conductance. Proc Natl Acad Sci USA 90:11429-11432.

Halliwell JV, Adams PR (1982) Voltage-clamp analysis of muscarinic excitation in hippocampal neurons. Brain Res 250:71-92. 
Harris EW, Cotman CW (1986) Long-term potentiation of guinea-pig mossy fiber responses is not blocked by $N$-methyl-D-aspartate antagonists. Neurosci Lett 70:132-137.

Hasegawa M, Cao Y, Adachi J (1992) Rodent polyphyly? Nature 335: 595.

Houser CR, Miyashiro JE, Swartz BE, Walsh GO, Rich JR, DelgadoEscueta AV (1990) Altered patterns of dynorphin immunoreactivity suggest mossy fiber reorganization in human hippocampal epilepsy. J Neurosci 10:267-282.

Jan I.Y, Jan YN (1982) Peptidergic transmission in sympathetic ganglia of the frog. J Physiol (Lond) 327:219-246.

Jiang HK, Owyang VV, Hong JS, Gallagher M (1989) Elevated dynorphin in the hippocampal formation of aged rats: relation to cognitive impairment on a spatial learning task. Proc Natl Acad Sci USA $86: 2948-2951$.

Khachaturian H, Watson SJ, Lewis ME, Coy D, Goldstein A, Akil H (1982) Dynorphin immunocytochemistry in the rat central nervous system. Peptides 3:941-954.

Kornblum HI, Hurlbut DE, Leslie FM (1987) Postnatal development of multiple opioid receptors in rat brain. Brain Res 465:21-41.

Lewis ME, Khachaturian H, Akil H, Watson SJ (1984) Anatomical relationship between opioid peptides and receptors in rhesus monkey brain. Brain Res Bull 13:801-812.

Madison DV, Nicoll RA (1988) Enkephalin hyperpolarizes interneurones in the rat hippocampus. J Physiol (Lond) 398:123-130.

Mansour A, Khachaturian H, Lewis ME, Akil H, Watson SJ (1987) Autoradiographic differentiation of $\mathrm{mu}$, delta, and kappa opioid rcceptors in the rat forebrain and midbrain. J Neurosci 7:2445-2464.

Mansour A, Fox CA, Meng F, Akil H, Watson SJ (1994) $k_{1}$ Receptor mRNA distribution in the rat CNS: comparison to $\kappa_{1}$ receptor binding and prodynorphin mRNA. Mol Cell Neurosci 5:124-144.

Martigaretti JA, Brosius J (1993) BC1 RNA as an evolutionary marker: guinea pig remains a rodent. Proc Natl Acad Sci USA 90:9698-9702.

Martin MR (1983) Naloxone and long-term potentiation of hippocampal CA3 field potentials in vitro. Neuropeptides 4:45-50.

McDaniel KL, Mundy WR, Tilson HA (1990) Microinjection of dynorphin into the hippocampus impairs spacial learning. Pharmacol Binchem Behav 35:429-435.

McGinty JF, Henriksen SJ, Goldstein A, Terenius L, Bloom FE (1983) Dynorphin is contained within hippocampal mossy fibers: immunochemical alterations after kainic administration and colchicine-induced neurotoxicity. Proc Natl Acad Sci USA 80:589-593.

McLean S, Rothman RB, Jacobson AE, Rice KC, Herkenham M (1987) Distribution of opiate receptor subtypes and enkephalin and dynorphin immunoreactivity in the hippocampus of squirrel, guinea pig, rat, and hamster. J Comp Neurol 255:497-510.

Moore SD, Madamba SG, Schweitzer P, Siggins GR (1994) Voltage- dependent effects of opioid peptides on hippocampal CA3 pyramidal neurons in vitro. J Neurosci 14:809-820.

North RA (1992) Cellular actions of opiates and cocaine. Ann NY Acad Sci 654:1-6.

North RA, Williams JT, Suprenant A, Christie MJ (1987) aa and $\delta$ receptors belong to a family of receptors that are coupled to potassium channels. Proc Natl Acad Sci USA 84:5487-5491.

Nowak RM (1991) Walker's mammals of the world. Baltimore: Johns Hopkins UP.

Sharif NA, Hughes J (1989) Discrete mapping of brain mu and delta opioid receptors using selective peptides: quantitative autoradiography, species differences and comparison with kappa receptors. Peptides 10:499-522.

Slater P, Cross AJ (1986) Autoradiographic distribution of dynorphin1-9 binding sites in primate brain. Neuropeptides 8:71-76.

Tempel A, Zukin RS (1987) Neuroanatomical patterns of the mu, delta, and kappa opioid receptors of rat brain as determined by quantitative in vitro autoradiography. Proc Natl Acad Sci USA 84:4308-4312.

Wagner JJ, Caudle RM, Chavkin C (1992) K-Opioids decrease excitatory transmission in the dentate gyrus of the guinea pig hippocampus. J Neurosci 12:132-141.

Wagner JJ, Terman GW, Chavkin C (1993) Endogenous dynorphins inhibit excitatory neurotransmission and block LTP induction in the hippocampus. Nature 363:451-454.

Weber E, Roth KA, Barchas JD (1982) Immunohistochemical distribution of alpha-neo-endorphin/dynorphin neuronal systems in rat brain: evidence for colocalization. Proc Natl Acad Sci USA 79:30623066.

Weisskopf MG, Zalutsky RA, Nicoll RA (1993) The opioid peptide dynorphin mediates heterosynaptic depression of hippocampal mossy fiber synapses and modulates long-term potentiation. Nature 362 : $423-427$.

Williams SH, Johnston D (1992) A novel action of endogenous opioids in the induction of hippocampal mossy fiber LTP. Soc Neurosci Abstr 403.

Wimpey TL, Chavkin C (1991) Opioids activate both an inward rectifier and a novel voltage-gated potassium conductance in the hippocampal formation. Neuron 6:281-289.

Xie G-X, Meng F, Mansour A, Thompson RC, Hoversten MT, Goldstein A, Watson SJ, Akil H (1994) Primary structure and functional expression of a guinea pig $\kappa$ opioid (dynorphin) receptor. Proc Natl Acad Sci USA 91:3779-3783.

Zalutsky RA, Nicoll RA (1990) Comparison of two forms of long-term potentiation in single hippocampal neurons. Science 248:1619-1624.

Zamir N, Quirion R, Segal M (1985) Ontogeny and regional distribution of proenkephalin- and prodynorphin-derived peptides and opioid receptors in rat hippocampus. Neuroscience 15:1025-1034. 